\title{
The International School's Culture in Indonesia and Brunei Darussalam
}

\author{
Muhammad Kristiawan', Suhono ${ }^{2 *}$, Mohd Hilmy Baihaqy Yussof ${ }^{3}$, Muslimah ${ }^{4}$ \\ ${ }^{1}$ Universitas Bengkulu, Indonesia \\ 2Institut Agama Islam Ma'arif NU Metro Lampung, Indonesia \\ ${ }^{3}$ Universiti Islam Sultan Sharif Ali (UNISSA), Brunei Darussalam \\ ${ }^{4}$ Institut Agama Islam Negeri Palangka Raya, Indonesia
}

@suhono120708@gmail.com

\begin{tabular}{|c|c|}
\hline \multirow{3}{*}{$\begin{array}{l}\text { ARTICLE INFO } \\
\text { Article history: } \\
\text { Received } \\
\text { December 23, } 2020 \\
\text { Revised } \\
\text { May 30, } 2021 \\
\text { Accepted } \\
\text { June 02, 2021 }\end{array}$} & ABSTRACT \\
\hline & $\begin{array}{l}\text { An understanding of a school's culture was essential to quality } \\
\text { management. In this study the researchers identified the international } \\
\text { school's culture in Singapore International School (SIS) Palembang, } \\
\text { Indonesia and Jerudong International School (JIS) Brunei Darussalam. } \\
\text { The approach used in this paper was qualitative, case study. The data } \\
\text { were collected by using observation and documentation. The data were } \\
\text { analyzed by using Miles and Huberman's Model. The results obtained } \\
\text { indicate that the school's culture in SIS was building students' character } \\
\text { such as honesty, sincerity, creativity, compliance with rules and norms. } \\
\text { While in JIS, the students should take responsibility for themselves and } \\
\text { others. They take the initiative, evaluate the situation in front of them and } \\
\text { make decisions accordingly. JIS thrives on mutual respect by working } \\
\text { with people from different backgrounds. }\end{array}$ \\
\hline & Keywords: School's Culture, SIS Palembang, JIS Brunei Darussalam \\
\hline How to cite & $\begin{array}{l}\text { Kristiawan, M., Suhono, S., Yussof, M., \& Muslimah., (2021). The International } \\
\text { School's Culture in Indonesia and Brunei Darussalam. Jurnal Iqra': Kajian Ilmu } \\
\text { Pendidikan, 6(1). 180-191. https://doi.org/10.25217/ji.v6i1.1263 } \\
\text { http://iournal.iaimnumetrolampung.ac.id/index.php/ii/ }\end{array}$ \\
\hline This is an open acce & $\begin{array}{l}\text { article under the CC BY SA license } \\
\text { https://creativecommons.org/licenses/by-sa/4.0/ }\end{array}$ \\
\hline
\end{tabular}

\section{INTRODUCTION}

This research started from browsing Singapore International School (SIS) Palembang. The website told the vision of SIS is "we provide holistic education to students in a caring environment, enabling them to contribute to the development of Indonesia". While the mission is "all school residents support students to develop the skills needed to be self-sufficient and able to manage themselves as successful young people who can contribute to Indonesia and the global community (Grant, et al., 2013; https://sisschools.org/). Furthermore, we browsed Jerudong International School (JIS) in Brunei Darussalam webstite and google scholar found that JIS students take responsibility for themselves and others. They take the initiative, evaluate the situation in front of them and make decisions accordingly. JIS thrives on mutual respect and looks to learn from the opportunities presented by working with people from different backgrounds (Wessam, 2020; Ho, 2014; Fitzgerald, 2010).

The researchers consider it is important to identify the school's culture in SIS and JIS because according to Robbins (2013), organizational culture refers to a system of shared meaning held by members that distinguish the organization from 
organizations. Daft (2007) also states that culture is the set of key values, beliefs, and norms shared by members of an organization. While West-Burnham (2008) \& Sumintono, et al., (2019) agues an understanding of a school's culture is essential to quality management. Then West-Burnham (2008) states culture is the shared understanding of an organization through rites, ceremonies, language, and social interaction.

This research is very important presented because supported by the latest global issue in education done by Faisol (2016) in Jambi. He found deliberation and spirit motivation to make the shift change for the better is cultural Madrasah religious and excellent in academic and extracurricular activities. Mukhtar (2016) in Jambi also found that the better the organizational culture will be better for the teacher career development system. Then, Tumiran (2015) in Medan, concluded the organization culture of the public primary school of Medan has a positive direct effect on the performance of teachers with a contribution of $1.06 \%$.

The next research was Mukhtar (2016) in Jambi told the better organizational culture will increase the professionalism of the Principal of SMP Negeri Jambi in leading the school. Riswan (2014) also found in Medan the culture of the organization has an indirect positive influence on job performance through job satisfaction for 1.12\%. While Andriani et al (2018); Salwa et al (2019) state transformational leadership and academic supervision have a positive and significant effect on the teachers' performance to produce good school culture. Then it produces the quality of human resources to answer the demand of the Asian Economic Community (Tobari, et al. 2018). Having the good quality of school's culture, it needs to improve the quality of teachers and education personnel, quality of facilities and infrastructure and quality of management (Irmayani, et. al. 2018; Wandasari et al, 2019).

Based on the grand tour, the theory and some researches above, we have good reason to identify the international school's culture in SIS and JIS. For that reason, we draw the school's culture is the identity of the school that distinguishes from other schools. School's culture is also able to influence the spirit of motivation in schools, teachers' career development system, teachers' performance, principal's professionalism and so on.

The reason the researchers conducted in SIS Palembang because SIS Palembang is the first Cooperation Education School (Satuan Pendidikan Kerjasama) in Palembang and has been established since 2012. SIS Palembang is a new school affiliated with SIS Indonesia. A good Singaporean curriculum is "internationalized" and adapted to sociocultural and local conditions. In addition, schools and students have many achievements, such as entering the best $30 \%$ of participants in international and local examinations, have graduated and proceeded to favorite university in the world such Raffles Institution in Singapore, Boston University, Royal Melbourne Institute of Technology in Australia and National University of Singapore, became the highestranking in Indonesia in the field of chemistry and physics in the examination of Cambridge (IGCSE) as well as the highest in all 7 subjects taken. The students of SIS also have good achievements in sport and art. Furthermore, we selected Jerudong International School, because JIS is one of the leading international schools in Brunei Darussalam. This research discussed what excellence will be achieved by SIS and JIS, how is the academic learning goals formulated, how does school physical facilities are well maintained, and how are the learning students and teachers' management. 


\section{School's culture}

The organizational culture is the identity of the organization, the uniqueness of an organization belongs to its culture. Culture is a product of shared values, beliefs, priorities, hopes and norms that serve to inform the way the organization manifests in the eyes of the world (West-Burnham, 2008). Organizational culture is a cognitive framework consists of attitudes, values, behavior norms, and shared expectations perceived by members of the organization (Berg and Baron, 2003). Organizational culture is an organizational life view generated through the turn of the generation. Culture includes who we are, what we believe, and what we do. Organizational culture is a belief, attitudes, and values that generally arise in an organization (Sedarmayanti, 2017). According to Kreitner and Kinicki, organizational culture is the values of beliefs underlying organizational identity (Sedarmayanti, 2017). While Schein (2004) states organizational culture is a series of implicit assumptions believed by the group and determining how the group sees, thinks, and reacts to its environment. Meanwhile, Robins (2002) argues organizational culture is a valuable system which distinguishes one organization and others. Sedarmayanti (2017) argues that organizational culture is the values, assumptions, attitudes, and norms of institutionalized behavior, then manifested in the appearance, attitude, and action then becomes a particular identity of organization.

Based on various opinions above, the researchers concluded that organizational culture is the result of the inventiveness, sense, and intention of the organizational members which creates values and norms then differentiates one organization with another organization. The values and norms in the organization come from the process of interaction among members to influence the attitude and behavior of its members. Organizational culture in this study is a school organizational culture or called the school's culture.

An effective school is manifested by the creation and maintenance of climate and culture for learning. Conducive climate and culture characterized by the creation of a safe and comfortable learning environment, then the learning will run effectively. It is very important that students feel happy and positive about their school, and the teachers feel appreciated, and parents and the community feel accepted and involved (Mulyasa, 2011). This can be realized through the creation of positive norms and habits, harmonious relationships and mutual respect. Also, a conducive school climate and culture encourage every citizen to act and do the best that leads to high achievement of students (Mulyasa, 2011).

The school's culture can be summarized as making a conducive school environment in which all school human resources feel secure and comfortable, and the learning will run effectively produces high students' achievement. The creation of a school's culture is relatively simple but the effect is quite satisfactory based on our assumption is to socialize $5 \mathrm{~S}$ by teachers which consist of senyum (smiles), salam (greetings), sapa (scold), sopan (polite) and santun (well mannered). Bergeson (2007) states teachers help create a supportive learning environment by conveying warm regard for students as well as high expectations for learning. This activity will certainly include all the human resources in the school, then the students will feel happy and positive towards the school, teachers feel appreciated, parents and community will feel proud of this school's culture.

According to Sedarmayanti (2017), the organizational culture indicators are 1) dominant characteristics; 2) organizational leadership; 3) employee management; 4) adhesive organization; and 5) strategy emphasis. Meanwhile Mulyasa (2011) argues the 
indicators of good school's culture are 1) what excellence will be achieved; 2) is the academic learning goals are formulated measurably; 3 ) is the school physical facilities are well maintained; 4) is the physical appearance of school clean, neat, and comfortable and pay attention to security; 5) is there affirmative posters (posters containing positive messages) are displayed in various strategic places that are easy and always seen by students; 6 ) does the school create for students and teachers a sense of belonging; 7) does the school make fun classroom condition; create an atmosphere that encourages students' for getting achievement; 8) does the important events at school are scheduled in such a way that they do not interfere with study time; 9) is there smooth and swift transition between activities at school; 10) do the teachers want to change teaching methods, when better methods are introduced to them; 11) does the school use moving-class on learning; 12) does the school create family relationship among others; 13) does the school create an atmosphere of hope, where teachers believe that students can achieve high levels of achievement; 14) does the school emphasize to students and teachers that learning is the most important reason to go to school; 15) does the school have expectation on high achievement of students are conveyed to students; 16) does the school have expectation on high achievement of students are conveyed to their parents; and 17) are all staff and teachers committed to develop a culture of quality in carrying out their daily tasks. The Mulyasa's indicators become an indicator of our interview instrument.

\section{METHOD}

This research was qualitative because 1) it is carried out under natural conditions; 2 ) it is more descriptive, the main data source is the words and actions, not to emphasize the numbers; 3 ) more emphasis on process than product or outcome; 4) data analysis is done inductively; and 5) emphasize more meaning (Sugiyono, 2011). Informants in this research were the Principal, Vice Principal, Head of School Administration, teachers, and students. The research instruments used were observation guides and documentation. The observation was conducted to find out the real activities and events about the school's culture of SIS Palembang and JIS Brunei Darussalam. Document study conducted by tracing the recording of events related to school culture SIS Palembang and JIS Brunei Darussalam. This is in line with Sugiyono (2011) who states that the document is the record of events that have passed. Documents may be in the form of writings, drawings, or monumental works of a person.

Content analysis is a research technique for making replicable and valid inferences from texts to the contexts of their use. As a technique, content analysis involves specialized procedures. It is learnable and divorceable from the personal authority of the researcher. The researchers used models of Miles and Huberman analysis, with the steps of data reduction, data model (data display) and the withdrawal of conclusions. As a research technique, the content analysis provides new insights, increases a researcher's understanding of particular phenomena, or informs practical actions (Krippendorff, 2018). The stages to be carried out in this study are the first is determining the theme. At this stage, researchers conducted more observations of data in the form of documents. Look for topics of interest and in this study topic of interest to researchers are finding a framework for a lifetime education the second is formulating the Problem. This stage is the reason why a topic is decided to be tested. This is done by researchers to formulate the problem with the chosen theme. The third is Collect data and determine research methods. Namely conducting theoretical studies 
related to the research topic. Literature sources can be obtained from books, journals, magazines, news, research results (thesis, thesis, and dissertation) and other relevant sources. The fourth is Analyze and compile the data findings. The last is draw conclusions. This stage is the answer to the research objectives which are at the conceptual/theoretical level. Researchers regularly arrange the data obtained so that they can conclude from the data that has been collected.

\section{RESULTS AND DISCUSSION \\ Singapore International School (SIS)}

School's culture in SIS is already run well. Education services in schools are part of public services, especially members of schools and society in general. Quality of service is a product according to established quality standards and customers' satisfaction. Quality in education includes the quality of inputs, processes, outputs, and outcomes. Outputs are eligible if the academic and non-academic learning outcomes of the students reach the prescribed standard.

The Government's effort on service and quality of education issued SchoolBased Management along with the determination of the output, process, and input criteria of education. First, the expected output of students' achievement both academic and non-academic meets the criteria specified. Students have National Students' Number to take National Examination and will be accepted to continue their study anywhere in Indonesia; second, the process is effective for teaching and learning process using English as the language of instruction of each subject, the school has a compact teamwork, intelligent, creative and dynamic, the school has autonomy, extracurricular like (fun cooking, comic writer, badminton, and others), school evaluation and continuous improvement; third, the input of the school has clear policies, objectives, and quality objectives, the curriculum of resources available, feasible and dedicated, the complete infrastructure consists of 40 classrooms, science laboratory, multipurpose hall, library, student resources, and IT Room.

SIS goals reflect the advantages achieved, it is demonstrated to all schoolchildren, established and widely publicized in schools in the form of school's vision and mission. The goals of academic learning are formulated measurably. SIS physical facilities are well maintained, including immediate repair of damaged facilities. The clean, neat and comfortable school physical appearance is caused by the cleaner team that stands by the school operational hours from morning to evening, as well as concerns the security with the SOP of SIS for security system consists of security officer equipped with uniform, school equipped with CCTV, schools also do not forget to coordinate with the police and the surrounding community. Thus, schools can be said to be safe for students. The yard and school environment are arranged in such a way that it gives the impression of beautiful, shady, and comfortable. Fun class conditions like being at home to create a comfortable atmosphere that encourages students for high achievement. Important events at school are scheduled in such a way that they do not interfere with study time.

SIS teachers wish to change their teaching methods. This is because the teachers are equipped with effective teaching because the teachers already have an undergraduate degree and some of them are undergoing master's degree lectures. Teachers at SIS are given training from their schools and one-time training per semester held by SIS in Indonesia to improve the knowledge and methods of teachers in teaching. 
SIS used the moving-class system. This is applied in changing learning strategies from classroom patterns to classrooms of study and each field of study has its class equipped with props and other tools. For moving-class implementation is done in the student resources room. Making family relationship and togetherness, this can be shown by the teachers' communication to parents related to problems experienced by students in the school. The parents and teachers equate the mission to solve the children's problem and parents can also accompany children to study at home. SIS creates an atmosphere of hope, where teachers believe that students can achieve high levels of achievement. Students who get a score below the prescribed standard are conducted remedial programs to assist them to improve the ability of certain subjects and they can ultimately achieve high levels of achievement.

All staff and teachers in SIS are committed to cultivating a patient attitude toward the students. This is because teachers and staff believe that being patient will cultivate integrity values for students. Evident at the time of physical education, the students can control themselves despite being busy playing but still follow the rules and safety culture. When they have to line up and enter the sports field they walk without mutual overtaking. When their teacher has not arrived, they already understand what equipment they need for the material on that day. That's what is cultivated by the school to students and then they are able, to be honest, sincere, creative, and obedient to the rules.

The school's culture developed by SIS being SIS's own identity, thus differentiating it from other schools. The findings of this research were consistent with the findings of Wardani (2015) in Salatiga which reveals that 1) cultural values develop in schools through a) written symbols such as school's vision, display guide behaviors, and message slogans; b) attitude of students' discipline on following lessons reach $100 \%$, health $97.04 \%$ (164 from 169 students), clean; the intelligence shown by passing rate of students for 3 years reaches $100 \%$ and the rate of class increase was $97.40 \%$ (from 192 students); superior student skills in playing band drums; virtuous in speech and honesty; devoted to God through religious lessons, flag ceremonies, and joint study activities; c) embedded beliefs are demonstrated by parents and students' trust in the school; 2) characteristics of cultural values that develop in schools include polite, caring for others and cooperation reached $84.22 \%, 87.52 \%$ and $84.81 \%$; 3) cultural character education follow persuasive communication approach, personal contact approach and role playing approach respectively 84,61\%; 84.02\% and 65.68\%; 4) educational values culture was applied effectively through familiarizing behavior, giving examples and creating a harmonious atmosphere.

The finding of Wardani has similar findings in this research. However, we see that our findings are more prominent to the use of English as the language of instruction of each subject, English language culture becomes more easily cultivated. This is because of SIS the first Cooperation Education School (Satuan Pendidikan Kerjasama) in Palembang. Meanwhile, Wardani's research was conducted in a state school which not integrated the international curriculum with the Indonesian standard curriculum. Our findings are also relevant to Wardani's finding (2014) in Yogyakarta. He found the model delivery of character values in the low grade of Primary School Taman Muda Ibu Pawiyatan Taman Siswa was integrated into all subjects. Moral values were developed through the learning of social sciences, citizenship, mathematics, Mulok (Arts/Songs of the Child, and learning the Javanese language).

Furthermore, our findings are supported by Kaur (2015) in India, he found that the answer is that it's not only teachers in schools that can impart moral education to 
the children, but that the parents also play a great role in making the children aware of the importance of leading life ethically. Our finding also relevant to the finding of Hammajam (2015) in Nigeria who states the attitude of parents under this research has great influences on the attainment of western education of their children.Barahate (2014) in India also supported our finding, he concluded teachers play an important role in the nation-building by character building of the students. The best and the greatest profession in the world is that of a teacher because the future of a nation depends upon the type of teachers who shape the future generations. Every teacher plays the most important role in shaping the students as enlightened citizens. Swami Vivekananda's words should not be forgotten by the teachers Arise, Awake and Stop not till the goal is achieved.

Bambaeeroo, and Shokrpour (2017) state the application of linguistic politeness in the school sphere is done through teacher attitude, communication with parents, and integrating character values in curriculum development. Some of the above studies showed that many aspects are involved in making the school's culture. All aspects must have collaborated to create an effective school's culture capable of fostering the students' character. Our findings were also supported by Mulyasa (2011), he states the school's culture is also concerned with the expectation on high achievement by all school citizens. Kristiawan et. al. (2017) argues that effective school organizational culture is the values and norms adopted and run by every person in the school's environment to achieve the vision, mission, and school's goals effectively and efficiently. Along with Robbins's opinion; Daft; West-Burnham then we believe that school's culture is the identity of the school itself which is characterized by school uniforms, the language used in teaching, the values and norms cultivated by schools in gaining the quality.

\section{Jerudong International School (JIS)}

Jerudong International School (JIS) opened its primary and secondary school in the year 1997, is currently a well-established school with a sound academic reputation. According to the report issued by the Independent Schools Inspectorate in May 2007, JIS is found to serves its pupils well. Indeed, JIS is one of the only 70 international schools belonging to the Headmasters and Headmistress Conference (HMS) and one of the only 120 Brutish School Overseas (BSO) Schools as well as an active member of the Federation of British International Schools in Asia (FOBISIA) and the Council of British International Schools (COBIS). JIS offers the British International Curriculum and prepares its students for GCSEs, IGCSEs, A-levels (AQA, Cambridge International Examinations, and Edexcel Board). It also offers the International Baccalaureate Diploma since it is an IB World School (Jerudong International School, 2018; Penta International, 2016).

According to the school descriptions, the school "Takes very seriously the statement that it is an international school and seeks to promote understanding of the wide variety of cultural traditions and beliefs represented in the school. It encourages debate about international affairs, the environment, modern history, global health interaction and friendship between young people of different ethnic groups and strives to promote international understanding practically and tangibly" (Jerudong International School, 2018). This shows that JIS is continuously committed to giving the students different kinds of exposure consisting of cultures and traditions with respecting an individual's faith and beliefs. 


\section{The School Vision, Values and Cultures at Jerudong International School (JIS)}

It is crucial to know the school vision and aims. This would indirectly instill the important values to the school communities, which would develop into the school cultures. For JIS, the mission of the school is to "Achieve Excellence". According to Sandow (2014), the JIS Principal, the vision means enabling every student to become the very best they can be. To achieve the school mission, 6 important elements were identified which emphases the school cultures. There are 1) encouraging participation; 2) integration; 3) enhancing leadership skills; 4) reinforcing language skills; 5) ensuring active engagement, and 6) developing thinking skills.

The learning cultures at JIS encourage the students to participate in a wide variety of activities to broaden their experience, finding things that they love which would enhance their learning self-esteem. The weekly program such as House Concerts and Sports has enabled them to be integrated easily with different societies and cultures as well as learn the mutual respect between their peers and the people around them (Sandow, 2014). At JIS, every student is given a variety of opportunities to develop their leadership skills. As their esteem and motivation grow, they can take ownership of their destiny to a greater extent by identifying their strength and interest.

Figure 1: The summary of School Cultures at JIS which strive towards holistic education.

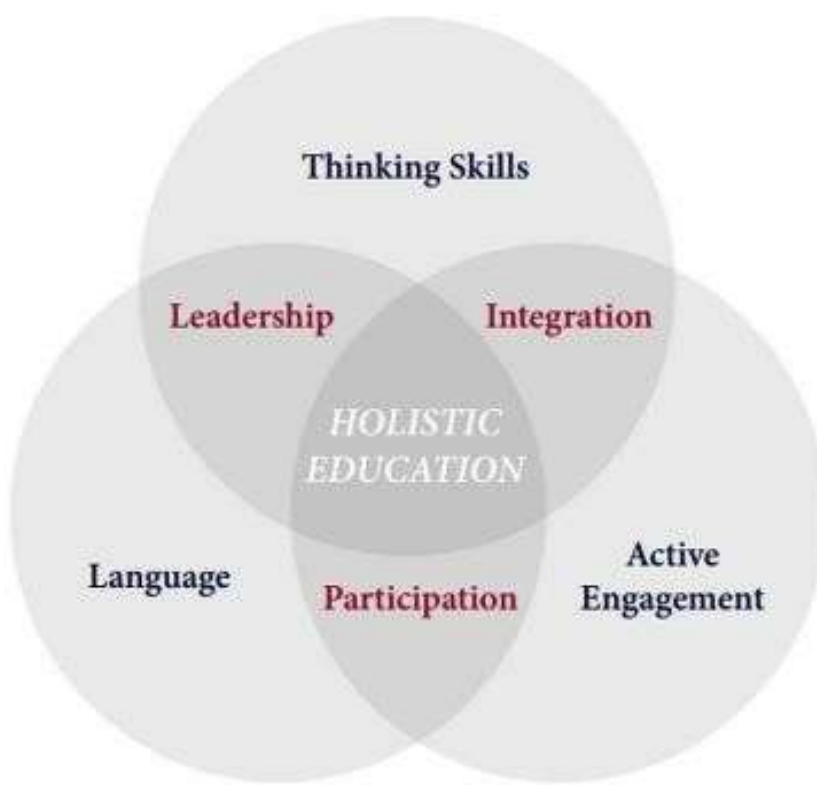

At JIS, the student's language and communication skills are reinforced through active participation in the classroom as well as during extra co-curriculum activities. By participating as a key role in the integrated societies breed the expectation of an active engagement within lessons. Through the student-centered approach that took place across every classroom, ensures the development of student's thinking skills. Thus, at JIS, the school cultures were instilled through the 6 elements that ensure holistic education to the students.

Strength of Jerudong International School (JIS) in Instilling Its Cultures

According to the Inspection report Jerudong International School (2016) and 
observations made by researchers, there is the strength of JIS consisting of the school education system and students attitudes, which are as follows:

1. The boarding and the day elements of the school are intimately connected, providing exemplary support for pastoral care and academic excellence.

2. It is observed that the attitudes of the students are excellent. They are passionate about the school. This due to the supportive staff of JIS whom regularly listened to the concerned of the students. The students are exposed to different kinds of opportunities which enable them to develop their leadership skills.

3. It is observed that the cultural and social development of the students is outstanding by learning and respecting various kinds of cultures during the classroom lesson and extra co-curricular activities and school functions.

4. Many staff committed well beyond contractual requirements in supporting and enthusing the students. This is due to the richness of learning resources that enable the staff to exposed different kind of learning environment towards the students.

5. The accommodation, facilities and resources at the school are excellent. This facilities are not limited to facilities inside the classroom but also facilities outside the classroom which could combine to support learning very effectively.

6. It is observed that the policies and implementation of procedures regulating the welfare, health, and safety of the students are excellent ensuring safety and security which inspire learning environment more effectively.

7. The information provided for parents is of high quality and much appreciated. The details provided for parents were very specific which enable them to identify the weakness and strength of their children performances in each subjects.

Form the above information, it is concluded that JIS has always been committed not only to provide student academic excellence but also devoted to instilling values and skills which enable the students to lead themselves, their communities as well as their organizations in the future.

This paper provides information for the stakeholders of schools both in Indonesia, Brunei Darussalam and other countries to build students' character by applying a good culture. Honesty, sincerity, creativity, responsibility and mutual respect will absolutely grow with the culture. The culture will be run effectively with the commitment all stakeholders of school. Having a positive school culture has an impact, not just on the attitudes of students and teachers, but on the entire learning experience. A school culture consists of the underlying influences and attitudes within the school. The prevailing atmosphere in school will affect everything that goes on inside its walls. When the school has a positive culture, teachers are excited to work because they see the bigger picture, and students are in a better position (mentally and emotionally) to learn (Raudys, 2018).

Culture is a deeper level of reflection of shared values, beliefs, and traditions between staff members. School leaders play a vital role in developing and enhancing the school culture. Positive school cultures provide a safe, supportive, encouraging, inviting, and challenging environment for students and staff, which in turn allows students' academic achievement to evolve (Confeld, 2016).

\section{CONCLUSION}

The SIS and JIS culture was seen from 1) school's goals are well-defined and widely publicized in the form of school's vision and mission; 2) the objectives of academic learning were formulated measurably; 3) school's physical facilities were 
well maintained, including promptly repaired damaged facilities; 4) school's physical appearance clean, neat, comfortable, and safe; 5) pleasant classroom conditions such as being at home, then arises comfortable atmosphere that encourages students' achievement; 6) important events at school are scheduled in such a way that they do not interfere with study time; 7) teachers are encouraged to implement varieties of teaching methods; 8) using moving-class systems; 9) making family relationship and togetherness through parents-teachers meeting; and 10) all staffs and teachers are committed to cultivating a patient attitude. That's what is cultivated by SIS and JIS to students to create honest, sincere, creative, and obedient citizenships.

\section{ACKNOWLEDGMENT}

We would like to express our special thanks and gratitude to our Rector Universitas Bengkulu, Universiti Islam Sultan Sharif Ali (UNISSA), Brunei Darussalam, Institut Agama Islam Ma'arif NU Metro Lampung and friends who gave us support to carry out this extraordinary project.

\section{AUTHOR CONTRIBUTION STATEMENT}

Muhammad Kristiawan (MK) was the main author in this article. MK, Suhono (S) and Mohd Hilmy Baihaqy Yussof (MHBY) jointly design research, collect data, and conduct analysis of the data obtained. Furthermore, this research can be completed properly. Muslimah (M) was the fourth author who helps editing manuscript.

\section{REFERENCES}

Andriani, S., Kesumawati, N., \& Kristiawan, M. (2018). The Influence of The Transformational Leadership and Work Motivation On Teachers Performance. International Journal of Scientific \& Technology Research, 7(7). Google Scholar

Bambaeeroo, F., Shokrpour, N. (2017). The Impact of the Teachers' Non-Verbal Communication on Success in Teaching. J Adv Med Educ Prof. 2017 Apr; 5(2): 51-59. Google Scholar

Barahate, Y. S. (2014). Role of a Teacher in Imparting Value-Education. IOSR Journal of Humanities and Social Science (IOSR-JHSS), International Conference on Advances in Engineering \& Technology-2014 (ICAET-2014). Google Scholar

Bergeson, T. (2007). Nine Characteristics of High Performing Schools. Washington: The Office of Superintendent of Public Instruction, Olympia. Google Scholar

Confeld, S. (2016). The Importance of a Positive School Culture. A Master's Project Presented to The Faculty of Adler Graduate School. Google Scholar

Daft, R. L. (2007). Organization Theory and Design. 9th Edition. The United States of America: South-Western. Google Scholar

Faisol, A. (2016). Transformational Leadership in Cultural Embedding Madrasah in Jambi Province. Journal of Research in Business and Management, Volume 4, Issue 9, Page 55-63. https://doi.org/10.29121/granthaalayah.v6.i11.2018.1087

Fitzgerald, K. W. (2010). Enhancing inclusive educational practices within secondary schools in Brunei Darussalam. Journal of the International Association of Special Education, 11(1), 48-55.Google Scholar

Grant, D., Koh, T. H., Tan, Y. E., Hsu, L. Y., Kurup, A., Donahue, S. K., ... \& Fisher, D. (2013). An outbreak of community associated methicillin resistant Staphylococcus aureus subtype USA300 at an International School in Singapore. Annals of the Academy of Medicine, Singapore, 42(11), 575-578. Google Scholar 
Hammajam A. A. (2015). Attitude of Parents toward Western Education in North Eastern Nigeria. Google Scholar

Ho, K. (2014). Public art education in Brunei Darussalam: The cultural language of community murals. Teaching Artist Journal, 12(1), 24-36 https://doi.org/10.1080/15411796.2014.844627

Irmayani, H., Wardiah, D., \& Kristiawan, M. (2018). The Strategy Of SD Pusri In Improving Educational Quality. International Journal of Scientific $\mathcal{E}$ Technology Research, 7(7). Google Scholar

Jerudong International School. (2018). Jerudong International School: History. Retrieved December 18, 2018, from Jerudong International School: http://www.jerudonginternationalschool.com/index.php/home/history

Kaur, S. (2015). Moral Values in Education. IOSR Journal Of Humanities And Social Science (IOSR-JHSS) Volume 20, Issue 3, Ver. III (March 2015), Page 21-26. Google Scholar.

Krippendorff, K. (2018). Content analysis: An introduction to its methodology. Sage publications. Google Scholar

Mukhtar. (2016). Analysis of Leadership Style and Oranizational Culture Effect on Career Development at Ministry Religious Affairs in Jambi Province. IOSR Journal of Business and Management (IOSR-JBM), Volume 18, Issue 11. Ver. IV (November. 2016), Page 65-74. Google Scholar

Mukhtar. (2016). Effect of Knowledge Managerial and Organizational Culture to Professionalism of Principal (A Study on SMP Negeri Jambi Province). IOSR Journal of Research \& Method in Education (IOSR-JRME), Volume 6, Issue 6 Ver. II (Nov. - Dec. 2016), Page 71-80.

Mulyasa, E. (2011). Manajemen dan Kepemimpinan Kepala Sekolah [Management and Principal Leadership]. Jakarta: Bumi Aksara.

Penta International. (2016). Inspection Report on Jerudong International School, Brunei. London: Penta International.

Riswan. (2014). The Influence of Principal Leadership, Organization Culture, Teacher Competency and Job Satisfaction to Job Performance of Teacher at Vocational Public School of Medan. IOSR Journal Of Humanities And Social Science (IOSRJHSS), Volume 19, Issue 3, Ver. V (March 2014), Page 50-53. Google Scholar

Robbins, S. P., \& Judge, T. A. (2013). Organizational Behavior. The United States of America: Prentice-Hall. Google Scholar

Raudys, J. (2018). 11 Real Ways to Build a Positive School Culture. Prodigy. https://www.prodigygame.com/main-en/blog/school-culture/

Salwa., Kristiawan, M., \& Lian, B. (2019). The Effect of Academic Qualification, Work Experience and Work Motivation towards Primary School Principal Performance. International Journal of Scientific \& Technology Research, 8(8). Google Scholar

Sandow, B. (2014). Jerudong International School. Retrieved November 15, 2018, from Jerudong International School. Google Scholar

Schein, E. H. (2004). Organizational Culture and Leadership. Third Edition, United States of America. Google Scholar

Sedarmayanti. (2017). Perencanaan dan Pengembangan Sumber Daya Manusia [Planning and Developing Human Resources]. Bandung: PT Refika Aditama. Google Scholar

Sugiyono. (2011). Metode Penelitian Kombinasi [Mix Methods]. Bandung: Alfabeta. Google Scholar 
Tobari., Kristiawan, M., \& Asvio, N. (2018). The Strategy of Headmaster on Upgrading Educational Quality In Asean Economic Community (AEC) Era. International Journal of Scientific \& Technology Research, 7(4). Google Scholar

Tumiran. (2015). The Impact of Transformational Leadership, Organizational Culture, Organizational Climate and Job Satisfaction of Teacher on Performance of Teacher at Public Primary School of Medan, North Sumatera. IOSR Journal Of Humanities and Social Science (IOSR-JHSS), Volume 20, Issue 6, Ver. II (Jun. 2015), Page 01-07. Google Scholar

Wandasari, Y., Kristiawan, M., \& Arafat, Y. (2019). Policy Evaluation of School's Literacy Movement on Improving Discipline of State High School Students. International Journal of Scientific \& Technology Research, 8(4). Google Scholar

Wardani, K. (2014). Proses Penanaman Nilai Budi Pekerti pada Pembelajaran Kelas Rendah di SD Taman Muda Ibu Pawiyatan Tamansiswa Yogyakarta [Process of Character Growth for Lower Education]. JIPSINDO No. 2, Volume 1, September 2014. Google Scholar

Wardani, N. S. (2015). Pengembangan Nilai-Nilai Budaya Sekolah Berkarakter [Developing the Value of School Culture]. Scholaria, Vol. 5, No. 3 , September 2015: 12-22. https://doi.org/10.24246/j.scholaria.2015.v5.i3.p12-22

West-Burnham, J. (2008). Managing Quality in Schools. Second Edition. London: Pearson Education Limited. Google Scholar

Wessam, H. (2020, July). Design and Fabrication of a Work Desk with Integrated Charging Ports, Desk Lamp and Storage Capability. In IOP Conference Series: Materials Science and Engineering (Vol. 884, No. 1, p. 012071). IOP Publishing. Google Scholar

\section{Copyright Holder :}

(C) Kristiawan, M., Suhono, S., Yussof, M., \& Muslimah, M. (2021).

First Publication Right :

(C) Jurnal Iqra' : Kajian Ilmu Pendidikan

This article is under:

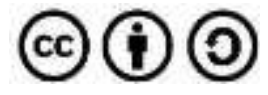

